УДК 615.453.4:615.322

DOI: $10.15587 / 2519-4852.2019 .158618$

\title{
PHARMACOTECHNOLOGICAL STUDIES OF MODEL SAMPLES IN THE DEVELOPMENT OF A COMPOSITION OF SOLID GASTROSOLUBLE CAPSULES
}

\author{
(C) L. Vyshnevska, Ye. Bysaha, D. Soldatov
}

\begin{abstract}
Мета: метою нашої роботи було експериментальне обтрунтування вибору допоміжних речовин у розробці складу твердих шлунковорозчинних капсул, призначених для лікування захворювань шлунковокишкового тракту.

Методи: застосовувались фармакотехнологічні методи дослідження.

Результати. Проведено дослідження з розробки складу та технології твердих желатинових шлунковорозчинних капсул із сухим екстрактом під умовною назвою урохолум. Вивчено вплив низки допоміжних речовин та сухого екстракту на фармакотехнологічні властивості порошкової маси для наповнення капсул за параметрами вологопоглинання, плинності та насипної густини. Встановлено оптимальні співвідношення наповнювачів та ковзних речовин до активної фармацевтичної субстанцї. Розроблено оптимальний склад капсул, щзо містять 50 мг сухого екстракту урохолуму та допоміжні речовини $в$ кількості 0,210 г (лактоза у кількості 0,2074 г та магнію стеарат - 0,026 г).

Аналіз технологічних параметрів капсул, виготовлених на основі розробленої композиції показав, щзо вони відповідають вимогам Державної фармакопеї Украӥни.

Висновки: експериментально доведено доцільність використання у складі капсул з сухим екстрактом урохолум комплексу допоміжних речовин лактоза у кількості - 0,2048 г та магнію стеарат - 0,026 г (на одну капсулу)

Ключові слова: желатинові капсули, склад, сухий екстракт, допоміжні речовини, технологія, илунковокишкові захворювання
\end{abstract}

\section{Introduction}

Despite the fact that on the global pharmaceutical market every year there are several dozen innovative and hundreds of generic drugs appearing, drug based on medicinal plant raw materials (MPRMs) continue to make up a significant share. Ukraine has not only favorable climatic conditions and a great variety of flora, but also a long history of the use of medicinal plant material. Curative properties of MPRMs have long been used in traditional and folk medicine, combining them with other methods of treatment.

Medicines are a disperse system consisting of active pharmaceutical ingredients and various auxiliary substances, each of which performs its tasks: active pharmaceutical ingredients provide a certain therapeutic effect, form-forming substances - the formation of a certain dosage form; substances that optimize the carrying out of technological processes provide the possibility of obtaining a pharmaceutical preparation that preserves the planned therapeutic function and other properties within the prescribed time.

Solid gelatin capsules provide a sufficient degree of tightness of the contents and stability of the medicinal product during their long-term storage, preventing the loss of volatile substances and the destruction of labile ingredients under the influence of adverse environmental conditions (oxygen air, humidity, direct sunlight, temperature). An important positive feature of capsules is the ability to fill them with powders of different physical and chemical properties, simplicity of technology and the absence of influence of factors associated with the technological features of the process of production of certain dosage forms (for example, local increase in temperature and pressure when pouring powder mixture or granulate) $[1,2]$.

2. Formulation of the problem in a general way, the relevance of the theme and its connection with important scientific and practical issues

In the manufacture of capsules, as a dosage form, one of the important parameters is the fluidity of the capsule mass, which ensures the precision of the dosage and the continuity of the capsule filling machine. To improve fluidity, auxiliary substances are added to the capsule mass: sliding (antifriction), lubricating, fillers, rinsers, moisture regulators (talc, aerosil, magnesium stearate, magnesium carbonate basic, carboxymethyl cellulose sodium salt, lactose, glucose, sucrose, etc.) $[3,4]$.

Taking into account the above, the definition of auxiliary substances and their optimal concentration is one of the approaches to solving the problem of uniform dosage of capsule mass in a capsule $[4,5]$.

3. Analysis of recent studies and publications in which a solution of the problem and which draws on the author

For several decades, scientific scientists such as M. V. Steinhart, E. E. Borzunov, M. A. Kazarinov, N. M. Asmolov, V. V. Nikityk and others engaged in scientific research in this direction. With the advent of new auxiliary substances, modern capsule filling machines, the problem of the development of technological mixtures (capsule masses) and today remains relevant for both new and generic drugs $[6,7]$. 


\section{Allocation of unsolved parts of the general problem, which is dedicated to the article \\ The main requirement for capsules, as dosage} forms, is homogeneity. According to the requirements of the SPHU for capsules, homogeneous content, mass, dosage units are tested. Homogeneity, in the first place, depends on the fluidity of the mass for encapsulation. The active substance of the capsules being developed is the total plant dry extract. Dry plant extracts are usually hygroscopic substances, have a tendency to form lumps and stick together, and as amorphous powders of the structure, have low volatility. The surface of the small particles of the substance is uneven, therefore between them the conditions for friction are created [8-11].

\section{Formulation of goals (tasks) of Article}

The aim of the work was to provide an experimental substantiation of the choice of auxiliary substances in the development of solid stomach-soluble capsules for the treatment of diseases of the gastrointestinal tract.
6. Statement of the basic material of the study (methods and objects) with the justification of the results

In the production of capsules, an important factor is the particle size distribution of powder, which has a significant effect on its fluidity, and as a consequence, affects the quality indices of the received technological mass, on the indicators of homogeneity of the dosage and other qualitative characteristics of the finished dosage form. The granulometric composition of the dry extract is given in Table 1.

As can be seen from the data of Table 1, the dry extract has a particle size that is close to the size of the filler particles (lactose), which will help obtain a homogeneous mixture of capsular mass without the use of granulation.

The introduction of auxiliary substances, in particular rupture agents, fillers, sliding and antifriction substances into the mass for encapsulation, is a necessary adjunct to improve its pharmaco-technological parameters.

Table 1

The fractional composition of the urocholum, dry extract

\begin{tabular}{|l|c|c|c|c|c|}
\hline \multirow{2}{*}{ Parameters } & \multicolumn{5}{|c|}{ Fractions } \\
\cline { 2 - 6 } & $\begin{array}{c}\text { less than } \\
0.09 \mathrm{~mm}\end{array}$ & $0.09-0.18 \mathrm{~mm}$ & $0.18-0.25 \mathrm{~mm}$ & $0.25-0.355 \mathrm{~mm}$ & $\begin{array}{c}\text { more than } \\
0.355 \mathrm{~mm}\end{array}$ \\
\hline Mass fraction, $\mathrm{g}$ & 4.940 & 6.850 & 7.920 & - & - \\
\hline Share of fraction, \% & 24.7 & 34.25 & 39.6 & - & - \\
\hline
\end{tabular}

To modern auxiliary substances there are the requirements for not having a toxic effect, to provide the necessary pharmacological action of a medicinal substance taking into account its pharmacokinetics, not to interact with the active pharmaceutical ingredient and technological equipment, be technological, do not show negative influence on the organoleptic properties of medicinal products (taste, smell, color, etc.), have a chemical and bacterial purity (do not exceed the norms established for certain drugs), be stable, economically affordable, etc.

When design the composition and technology of the drug, usually used excipients that are widely used in pharmaceutical practice and permitted for medical use. These fillers (lactose, magnesium carbonate), to improve the flow to the capsule mass add talc, aerosil, to facilitate the release of subpressed capsule mass from the dosage device using lubricants (magnesium stearate), moisture regulators are designed to reduce the absorption of moisture by dry extract (magnesium carbonate, etc).
To select the optimal composition of auxiliary substances for developed capsules, taking into account the moisture content of dry extract, which was $4.16 \%$, we received the following compositions (Table 2).

The capsule mass should have sufficient fluidity for the normal operation of the dispensing device, which depends to a large extent on the design of the dispensing device. Typically, the fluidity of the capsule mass greater than $4 \mathrm{~g} / \mathrm{s}$ is sufficient. A mixture for filling capsules was obtained as follows. The components were sieved and weighed. The laboratory mixer with a rotational speed of 45-60 min was charged with lactose and dry extract, stirred to obtain a homogeneous mass, and then sliding and / or antifriction substances were added in accordance with the composition and again stirred for 10-15 minutes.

Investigation of mass fluidity for encapsulation was carried out according to the method 2.9.16 of SPHU (vibration test method) [6]. The results of the study are presented in the Table 3 .

Table 2

Composition of model capsules of urocholum

\begin{tabular}{|c|l|c|c|c|c|c|}
\hline \multirow{2}{*}{ No. } & \multicolumn{1}{|c|}{ Ingredient } & \multicolumn{5}{c|}{ Composition per capsule, mg } \\
\cline { 3 - 7 } & & F1 & F2 & F3 & F4 & F5 \\
\hline 1 & $\begin{array}{l}\text { Dry extract in terms of } \\
\text { dry basis }\end{array}$ & 0.0500 & 0.05 & 0.0500 & 0.0500 & 0,0500 \\
\hline 2 & Lactose & 0.2100 & 0.2074 & 0.2061 & 0.2022 & 0,1970 \\
\hline 3 & Magnesium stearate & - & 0.0026 & - & - & - \\
\hline 4 & Aerosil & - & - & - & - & 0,013 \\
\hline 5 & Talc & - & - & 0.0039 & 0.0078 & - \\
\hline Total: & 0,2600 & 0.2600 & 0.2600 & 0.2600 & 0.2600 \\
\hline
\end{tabular}


Fluidity of model samples of capsule masses

\begin{tabular}{|l|c|c|c|c|c|}
\hline \multirow{2}{*}{\multicolumn{1}{|c|}{ Indicator, dimension }} & \multicolumn{5}{|c|}{ No. of sample } \\
\cline { 2 - 6 } & F1 & F2 & F3 & F4 & F5 \\
\hline Fluidity, g / s & 1.44 & 1.26 & 1.18 & 1.00 & 0.82 \\
\hline Bulk density, g / ml & 0.695 & 0.654 & 0.679 & 0.670 & 0.524 \\
\hline Bulk density after shrinkage, g/ml & 0.850 & 0.833 & 0.860 & 0.860 & 0.653 \\
\hline Loss in mass after drying, \% & 1.09 & 1.27 & 1.22 & 1.32 & 1.35 \\
\hline
\end{tabular}

As can be seen from the data in Tab. 3, none of the composition ensures sufficient mass of the mass necessary for the continuous operation of the capsule machine and the accuracy of the dosage of medicinal substances. The addition of excipients did not improve fluidity, and somewhat even worsened it. Based on the results of our studies, we decided to change lactose with flow rate $1.52 \mathrm{~g} / \mathrm{sec}$ to lactose with the flow rate $6.0 \mathrm{~g} / \mathrm{s}$

The above-mentioned technology prepares model samples of capsules of the following composition (Table 4). The results of studies of capsule mass of manufactured model models using lactose 80 mesh are given in Table 5 .

Table 4

Composition of model specimens of capsules using lactose 80 mesh

\begin{tabular}{|c|c|c|c|c|c|c|}
\hline \multirow{2}{*}{ No. } & \multirow[t]{2}{*}{ Ingredient } & \multicolumn{5}{|c|}{ Composition per one capsule, $\mathrm{mg}$} \\
\hline & & $\mathrm{F} 1 *$ & $\mathrm{~F} 2 *$ & F3* & F4* & $\mathrm{F}^{*} *$ \\
\hline 1 & $\begin{array}{l}\text { Dry extract in terms of } \\
\text { dry basis }\end{array}$ & 0.0500 & 0.0500 & 0.0500 & 0.0500 & 0,0500 \\
\hline 2 & Lactose 80 mesh & 0.2100 & 0.2074 & 0.2061 & 0.2022 & 0,1970 \\
\hline 3 & Magnesium stearate & - & 0.0026 & - & - & - \\
\hline 4 & Aerosil & - & - & - & - & 0,013 \\
\hline 5 & Talc & - & - & 0.0039 & 0.0078 & - \\
\hline \multicolumn{2}{|c|}{ Total: } & 0,2600 & 0.2600 & 0.2600 & 0.2600 & 0.2600 \\
\hline
\end{tabular}

Results of research of model samples of capsules with lactose 80 mesh

\begin{tabular}{|l|c|c|c|c|c|}
\hline \multirow{2}{*}{\multicolumn{1}{|c|}{ Indicator, dimension }} & \multicolumn{5}{|c|}{ No. of composition } \\
\cline { 2 - 6 } & $\mathrm{F} 1^{*}$ & $\mathrm{~F} 2^{*}$ & $\mathrm{~F} 3^{*}$ & $\mathrm{~F} 4^{*}$ & F $^{*}$ \\
\hline Fluidity, g/s & 5,04 & 4,58 & 4,58 & 5,04 & 2,39 \\
\hline Bulk density, g/ml & 0,678 & 0,680 & 0,690 & 0,741 & 0,541 \\
\hline $\begin{array}{l}\text { Bulk density after shrinkage, } \\
\text { g/ml }\end{array}$ & 0,800 & 0,800 & 0,800 & 0,833 & 0,656 \\
\hline Loss in mass after drying, \% & 1,36 & 1,76 & 0,93 & 0,81 & 1,05 \\
\hline
\end{tabular}

As can be seen from the data in Tab. 5, when using as a lactose 80 mesh filler, the introduction of talc in the amount of $1.5 \%$ (composition F3*) instead of magnesium stearate (composition $\mathrm{F} 2 *$ ) does not change the fluidity index. An increase in the amount of talc of up to $3 \%(\mathrm{~F} 4 *)$ compared to $1.5 \%(\mathrm{~F} 3 *)$ increases fluidity, but not significantly.

The introduction of an aerosil (composition $\mathrm{F} 5^{*}$ ) worsens this parameter, the value of the bulk density decreases.

So, F2* containing a magnesium stearate lubricant for the normal operation of the dispenser, has sufficient fluidity and bulk density for dosage of the capsule mass of the urocholum in capsule No. 2.

\section{Conclusions from the conducted research} and prospects for further development of this field

1. The choice of dosage form - solid gastrosoluble capsules intended for the treatment of diseases of the gastrointestinal tract is substantiated.

2. The influence of a number of auxiliary substances on the pharmaco-technological parameters of capsules with dry extract - urocholum was studied. The optimal proportions of excipients to the active pharmaceutical substance are established. The optimal composition of capsules containing $50 \mathrm{mg}$ dry extract of urocholum and auxiliary substances in the amount of $0.210 \mathrm{~g}$ (lactose, the fluidity of which is $6.0 \mathrm{~g} / \mathrm{s}-0.2048 \mathrm{~g}$ and magnesium stearate $-0.026 \mathrm{~g}$ ) is developed.

\section{References}

1. Formulation and physical properties of thixotropic gels for hard gelatin capsules / Walters P. A. et. al. // Drug Development and Industrial Pharmacy. 1992. Vol. 18, Issue 15. P. 1613-1631. doi: https://doi.org/10.3109/03639049209040890

2. Suchasnyi stan stvorennia, vyrobnytstva i kontroliu yakosti kapsul / Chubka M. B. et. al. // Farmatsevtychnyi chasopys. 2012. Issue 2. P. $165-168$.

3. Lasing cholesteric capsules / Dudok T. et. al. // Ukrainian Journal of Physical Optics. 2016. Vol. 17, Issue 4. P. 169. doi: https://doi.org/10.3116/16091833/17/4/169/2016 
4. Pertsev I. M., Rybachuk V. D., Dmytrievskyi D. I. Dopomizhni rechovyny v tekhnolohii likiv: vplyv na tekhnolohichni, spozhyvchi, ekonomichni kharakterystyky i terapevtychnu efektyvnist / ed. by Pertsev I. M. Kharkiv: Zoloti storinky, 2010. 600 p.

5. Felle I., Whiteside R., Vollmer R. Alternatives for lactose // News technical, JRS Pharma. 2007. P. 10-12.

6. Kazarinov M. O., Shteinhart M. V., Pashneva R. O. Tverdi likarski formy: pidsumky ta perspektyvy rozrobok tekhnolohichnykh laboratoriy DP DNTsLZ // Farmakom. 2005. Issue 2-3. P. 18-24.

7. Tekhnolohyia i standartyzatsyia lekarstv. Vol. 2 / ed. by Heorhyevskoho V. P., Koneva F. A. Kharkiv: RYREH, 2000. $784 \mathrm{p}$.

8. Ennis B. Theory of Granulation // Drugs and the Pharmaceutical Sciences. 2005. P. 7-78. doi: ttps://doi.org/10.1201/9780849354953.ch2

9. Derzhavna Farmakopeia Ukrainy. Vol. 1. Kharkiv: DP «Ukrainskyi naukovyi farmakopeinyi tsentr yakosti likarskykh zasobiv», 2015. 1128 p. 2007. $4372 \mathrm{p}$

10. Encyclopedia of pharmaceutical technology / J. Swarbrick (Ed.). 3-rd ed. New York: Informa Healthcare USA, Inc.,

11. European Pharmacopoeia 9.0. URL: http://online6.edqm.eu/ep900

Дата надходження рукопису 28.01.2019

Dmytro Soldatov, PhD, Department of Industrial Pharmacy, National University of Pharmacy, Pushkinska str., 53, Kharkiv, Ukraine, 61002

E-mail: soldatovdp@gmail.com

Liliia Vyshnevska, Doctor of Pharmaceutical Science, Department of Pharmaceutical Technology of Drugs, National University of Pharmacy, Pushkinska str., 53, Kharkiv, Ukraine, 61002

E-mail: liliiavyshnevska@gmail.com

Elizaveta Bysaha, Department of Pharmaceutical Technology of Drugs, National University of Pharmacy Pushkinska str., 53, Kharkiv, Ukraine, 61002

E-mail: bisagaliza@gmail.com 